\title{
Multiple perceptible signals from a single olfactory glomerulus
}

\author{
Dmitry Rinberg \\ From 1st International Workshop on Odor Spaces \\ Hannover, Germany. 4-7 September 2013
}

Glomeruli are functional units in the olfactory system. The mouse olfactory bulb contains roughly 2,000 glomeruli, each receiving inputs from olfactory sensory neurons (OSNs) that express a specific odorant receptor gene. Odors typically activate many glomeruli in complex combinatorial patterns and it is unknown what features of neuronal activity in individual glomeruli contribute to odor perception. To address this, we used optogenetics to selectively activate single, genetically identified glomeruli in behaving mice. We find that mice can perceive the stimulation of a single glomerulus. Single- glomerulus stimulation can also be detected on an intense odor background. In addition, different input intensities, and the timing of input relative to sniffing can be discriminated through one glomerulus. Our data reveal that each glomerulus can transmit odor information using identity, intensity, and temporal coding cues. These multiple modes of information transmission may enable the olfactory system to efficiently identify and localize odor sources.

Submit your next manuscript to BioMed Central and take full advantage of:

- Convenient online submission

- Thorough peer review

- No space constraints or color figure charges

- Immediate publication on acceptance

- Inclusion in PubMed, CAS, Scopus and Google Scholar

- Research which is freely available for redistribution 